\title{
BEHAVIOURAL RESPONSES OF TWO JAPANESE QUAIL LINES DIFFERING IN BODY WEIGHT TO HEAT STRESS
}

\author{
H.A. Khali1 ${ }^{1}$, M. Gerken ${ }^{2}$, A.M. Hassanein ${ }^{1}$ and M. E. Mady ${ }^{1}$ \\ 1- Department of Animal Production, Faculty of Agriculture, Suez Canal University, Ismailia, \\ Egypt, 2- Department of Animal Science, Georg-August-University, Goettingen, Germany
}

\section{SUMMARY}

The objectives of this experiment were to study the effects of different environmental temperatures during the rearing phase on the heat tolerance and behavioral responses of two Japanese quail lines to heat stress. A total of 192 chicks from two lines were randomly distributed between eight brooding cages. Each line was divided into 4 treatments. Each treatment was different in experimental period of exposure to $35^{\circ} \mathrm{C}$ heat $\left(2,3,4\right.$ and 5 weeks after that the temperature was reduced to $\left.25^{\circ} \mathrm{C}\right)$. The behavioral traits were determined during the first 5 weeks of age. Also, temperature preference test was done and rectal and leg temperatures and latency until panting were determined after 10 weeks from the starting of the experiment.

Results indicated that birds under heat stress changed their behavior significantly. They tended to spend more time sitting and less time standing, walking and feeding. Increase of environmental temperature during the rearing phase leads to an increase in the heat tolerance in Japanese quail. The light quail line was more active and tolerated heat better than the heavy quail line under heat stress.

The results obtained could contribute new aspects to a better understanding of thermo-regulative process in Japanese quail. It can allow for developing of new housing and production systems that are more suitable for a specific climatic condition.

\section{Keywords: Japanese quail, heat stress, behavioural traits, heat tolerance}

\section{INTRODUCTION}

The environment includes all external factors (temperature, population density, light, humidity, etc.) as well as internal factors (pathogenic organisms, parasites, or any other foreign substance). Any change in the environment will cause both specific and nonspecific responses reactions that are directed at re-establishing a state of homeostasis in the bird. To maximize meat or egg production, poultry producers must do every thing possible to minimize the number and intensity of stressors within the poultry house. One stressor, which is common to poultry, especially in summer months and in tropical areas, is heat (Siegel, 1980; Ali et al., 1980; Richard et al., 1998; Khalil, 2004, Khalil et al., 2006, 2007and 2008).

The negative effects of heat stress on poultry are widely known since a long time. High housing temperature $\left(35^{\circ} \mathrm{C}\right)$ had negative effects on body weight, feed efficiency, carcass yield and survivability of the Japanese quail (Michael et al., 1996; Khalil, 2004; Khalil et al., 2006, 2007 and 2008). Furthermore, heat stress caused a series of physiological and metabolic changes in avian species such as elevated body temperature, panting and respiratory alkalosis (Deyhim and Teeter, 1991 and Khalil, 2004) and reduced thyroid activity (Bowen and Washburn, 1985).
This experiment was conducted to compare the reactions to heat stress of two Japanese quail lines differing in body size. The experiment was also designed to detect whether the environmental temperature during the rearing phase could influence the heat tolerance and behavior in either of these lines.

\section{MATERIALS AND METHODS}

\section{Birds and husbandry:}

This experiment took place at the Poultry Farm, Institute of Animal Breeding and Genetics, University of Goettingen, Germany. One hundred and two unsexed one-day-old Japanese quail chicks from light and heavy body weight lines were randomly distributed between eight brooding cages (20-30 chicks / cage). Each brooding cage $(100 \times 50 \times 40 \mathrm{~cm})$ had two heaters (white light, 250 Watt) set in the ceiling. The temperature of the heaters was controlled by a dimmer switch. The floors consisted of a mesh made from strips of green plastic. At the end of each cage, there was a wooden box $(50 \times 30 \times 5 \mathrm{~cm})$, divided into two sections, one for sand (dust bathing) and the other for straw (egg laying). At the front of each cage, there was a feeder and water. Feed, water, sand and straw were available ad libitum.

Sex differentiation was done at three weeks of age. All chicks were wing banded to 
register their pedigree. At five weeks of age, all the birds were transferred from the brooding cages into eight floor pens $(80 \times 130$ $x 70 \mathrm{~cm})$. The ceiling of the pens was made of polyvinyl netting (mesh size four $\mathrm{cm}^{2}$ ). Woodshavings were used as a litter. In each pen contained a feeder, two automatic cups and two wooden boxes with straw. Feed, water and straw were available ad libitum. The average body weight of the light and heavy quail lines at 6 weeks of age were 100 and $290 \mathrm{~g}$ respectively.

The poultry farm had a closed side housing system so that the room temperature and light period could be artificially controlled. A fluorescent tube (58 Watt) was suspended from the ceiling to light the room. The light came on at $0600 \mathrm{~h}$ to $2200 \mathrm{~h}$, with a $15 \mathrm{~min}$ twilight phase at the start and the end of the light period. The light intensity in both the brooding cages and pens ranged from 35 - 40 Lux in the front to $8-10$ Lux at the back. The birds were subjected to $23 \mathrm{~L}$ to $1 \mathrm{D}$ for the first day posthatching and 20L to 4D on day 2 until the end of the first week. At the beginning of the second week, the light was changed to give 16L - 8D. This regime was maintained until the end of the experiment.

\section{Treatments:}

Two Japanese quail lines differing in body size and two different brooding environmental temperatures $\left(25^{\circ} \mathrm{C}\right.$ and $\left.35^{\circ} \mathrm{C}\right)$ were used in this experiment. Each line was divided into 4 groups according to the period of brooding under $35^{\circ} \mathrm{C}$. The $1^{\text {st }}, 2^{\text {nd }}, 3^{\text {rd }}$, and $4^{\text {th }}$ groups were kept under $35^{\circ} \mathrm{C}$ for $2,3,4$ and 5 weeks from hatching, respectively. Subsequently, the ambient temperature for all the groups was reduced to $25^{\circ} \mathrm{C}$.

\section{Traits Studied: \\ Behavior:}

The behavioral traits of all the groups were determined during the first five weeks of life using a video camera in each brooding cage. The behavioral traits were recorded one day a week during the period of light from 0600 to $2200 \mathrm{~h}$ (every 20 minutes) as follows:

a- Basic activities (percentage of birds standing, sitting or walking),

b- Additional activities (percentage of birds feeding, drinking or preening).

\section{Temperature Preference Test:}

This test was done at 10 weeks of age. The aim of this test was to see whether the rearing treatment had an influence on the temperature preference of adult quail for either $25^{\circ} \mathrm{C}$ or $35^{\circ} \mathrm{C}$. This test also measures the ability of adult quail to freely choose the optimal ambient temperature for quail which is $25^{\circ} \mathrm{C}$.

\section{Equipment:}

The equipment consisted of two brooding cages joined together with a small opening (diameter $15 \mathrm{~cm}$ ) in the middle, so that the birds could move easily between the two compartments (Figure 1). Each cage was equipped with two heaters and a video camera.

\section{Methods:}

All birds were randomly divided into 24 groups according to treatment and line [(12 groups/line) and/or (three groups/treatment)]. Each group consisted of 2-5 birds from the same line. Every group was kept in the test situation during the period of light from 06:00 to $22: 00 \mathrm{~h}$.

Each group was kept in the test situation for two successive days. Every bird was tested only once during the period of light from 06:00 to $22: 00 \mathrm{~h}$. On day one, the birds were put in Unit 1 randomly either in the compartment for $25^{\circ} \mathrm{C}$ or for $35^{\circ} \mathrm{C}$. On day two, the birds were put in Unit 2 in the same side (left or right) as on day 1 , but this time the compartment had the other ambient temperature (Figure 1). The behavior of the birds was recorded every 10 minutes using the two video cameras in each double-caged unit as follows:

a- Distribution of birds (\%) in the two compartments (preferred temperature 25 or $\left.35^{\circ} \mathrm{C}\right)$.

b- Basic activities (percentage of birds in each cage standing, sitting or walking).

c- Additional activities (percentage of birds in each cage: feeding, drinking or preening).

\section{Room temperature and relative humidity:}

Room and cage temperatures and relative humidity were recorded every two min during the whole experiment using a digital thermohydrometer. The average temperature and relative humidity in heat stress and control groups were $\left(35.25 \pm 1.15^{\circ} \mathrm{C}, 17.56 \pm 7.25 \mathrm{RH}\right.$ and $\quad 25.23 \pm 1.26^{\circ} \mathrm{C}, \quad 30.62 \pm 8.7 \quad \mathrm{RH}$, respectively).

\section{Short-term heat stress test: Aim:}

The aim of this test was to evaluate the bird's adaptive reactions towards short-term heat stress $\left(30\right.$ minutes at $\left.35^{\circ} \mathrm{C}\right)$. Leg temperature was used in this test. It was chosen as indirect measures for core body temperature by infrared thermography equipment was used in this test (The Thermovision (R) 900 system; AGEMA, 1992).

\section{Method:}

A total of 40 birds were used in this test according to treatment and line (each treatment 
group consisted of five birds). The birds were chosen randomly and each was subjected individually to $35^{\circ} \mathrm{C}$ for 30 minutes in the testing cage. Thirty-one pictures were taken for every bird during the test (one picture / minute). Each bird was tested only once at 10 weeks of age.

\section{Traits studied under heat stress:}

1- Leg temperature $\left({ }^{\circ} \mathrm{C}\right)$. 2- Time to start of panting (minutes) when subjected to heat stress. 3- Rectal temperature $\left({ }^{\circ} \mathrm{C}\right)$ before and after the test.

\section{Statistical analyses:}

Values are presented as means \pm SE. Data were analyzed using the General Linear Model (GLM) procedure of SAS (SAS Institute Inc., 1998), and the significant differences between means were detected according to Duncan's multiple range test (Duncan, 1955). A probability value $(\mathrm{P})$ of less than 0.05 was considered to be significant.

\section{RESULTS}

\section{Behaviour:}

Basic behavioural activities:

The Basic behavioural activities (standing, sitting and walking) of quail were significantly influenced by treatments. Light weight birds spent more time standing in the control and 3-weeks heat stress groups compared with the other heated groups. The lowest percentage of sitting and the highest percent of walking were obtained in control group. On the other hand, in the heavy weight line, percentage of standing decreased, but percentage of sitting and walking increased with increasing length of rearing under $35^{\circ} \mathrm{C}$ (Table 1).

The heavy quail line spent significantly more time sitting than the light quail line (51.70 vs. $48.52 \%$, respectively). Contrary to that, light birds walked significantly more than the heavy quail (16.13 vs. $11.50 \%$, respectively), irrespective of the different rearing temperatures (Table 1).

\section{Additional behaviour activities:}

The traits studied (preening and feeding) were significantly influenced by the rearing temperatures, line and their interactions. Light birds spent more time preening and feeding in the control and 3-weeks high brooding temperature groups compared with the other heated groups. However, in the heavy birds the control and 4 weeks high brooding temperature groups spent more time preening than the other heated groups. The lowest percentage of feeding was obtained in 5 weeks high brooding temperature groups, while the highest percentage was obtained in the control group (Table 2).

Also, significant differences $(\mathrm{P} \leq 0.05)$ among the two lines in additional behaviour activities percentage were found. The heavy birds spent significantly more time feeding and drinking than the light birds (10.22 vs. $8.81 \&$ 3.57 vs. $2.4 \%$, respectively). Conversely, higher percentage of preening was obtained in the light birds than in the heavy birds (13.27 vs. $10.22 \%$, respectively), irrespective of the different rearing temperatures.

\section{Preference test:}

Preferred ambient temperatures of the two quail lines as affected by different rearing temperatures at 10 weeks of age are presented in Table (3).

There were significant differences $(\mathrm{P} \leq 0.05)$ between the two ambient temperatures used in the preference test $\left(25^{\circ} \mathrm{C}\right.$ as control \& $35^{\circ} \mathrm{C}$ as heat stress) on choosing temperatures. Higher percentage of the birds preferred a $25^{\circ} \mathrm{C}$ compared to the $35^{\circ} \mathrm{C}$ irrespective of rearing temperatures, lines and length of brooding temperature at $35^{\circ} \mathrm{C}(76.48$ vs. $23.57 \%$, respectively). Also there are significant differences between lines and the ambient temperatures used in the preference test $\left(25^{\circ} \mathrm{C}\right.$ $\& 35^{\circ} \mathrm{C}$ ). The light weight birds spent more time under high ambient temperatures compared with the heavy weight birds (30.62 vs. $16.56 \%$, respectively).

\section{Short term heat stress test: \\ Rectal temperatures:}

Data in Table (4) show Least Square Means of the rectal temperatures $\left({ }^{\circ} \mathrm{C}\right)$ in the light and heavy quail lines in relation to a short-term heat stress (across $30 \mathrm{~min}$ ) as affected by rearing temperatures.

Analysis of variance revealed significant differences $\quad(\mathrm{P} \leq 0.05) \quad$ between rearing temperatures and lines on rectal temperatures before (RTB) and after heat stresses (RTA), but the interactions were not significant. Before heat stress, the highest values were obtained in the control and the five weeks heat stress group. However, after heat stress, the control groups had the highest values compared with the heated groups. The differences between RTA and RTB between rearing temperatures and lines were not significant.

Heavy birds had significantly higher rectal temperatures than light quail before and after heat stress $\left(42.28\right.$ vs. $41.83^{\circ} \mathrm{C}$ RTB and 42.96 vs. $42.48^{\circ} \mathrm{C}$ RTA, respectively). These results indicate that, small quail had more heat tolerance than the heavy quail. In addition, exposing birds to longer periods of high temperature $\left(35^{\circ} \mathrm{C}\right)$ during the rearing phase 
helped to improve the heat tolerance in adult quail.

\section{Leg temperatures by infrared thermography:}

Significant effects were found for rearing treatments and the interaction between treatments and lines in leg temperatures. Light females had the lowest values in the 2 and 3 weeks of high heat brooding groups. While the heavy weight quail line had the lowest value in the 5 weeks heated group compared with the other groups. Heavy line had higher leg temperature than the light birds (37.43 vs. $37.18^{\circ} \mathrm{C}$, respectively) irrespective of rearing temperatures (Table 5).

It is concluded that increasing environmental temperature during early age will result in thermal conditioning which can lead to increasing heat tolerance in heat stressed groups.

\section{Latency until panting:}

The effect of different rearing temperatures on latency until panting (min) in the light and heavy quail lines in relation to short-term heat stress are presented in Table (6).

Latency is defined as the time interval (min) from the exposure to heat stress $\left(35^{\circ} \mathrm{C}\right)$ until the start of panting. Control birds started panting significantly earlier than other heat stressed groups in both lines. Significant differences $(\mathrm{P} \leq 0.05)$ were also found between the two lines, the heavy quail line starts panting earlier than the light females (5.28 vs. 8.39 min, respectively).

\section{DISCUSSION}

The results of this experiment showed that, behavioral thermoregulation is one of the most important responses of birds to heat stress. Behaviour of quail birds was changed significantly by rearing temperatures (short and long rearing periods at $35^{\circ} \mathrm{C}$ ). Birds reared at $35^{\circ} \mathrm{C}$ tended to spent more time sitting and less time standing and walking as compared with the $25^{\circ} \mathrm{C}$ group.

Also, birds reared at $35^{\circ} \mathrm{C}$ for along period reduced the amount of feed they consumed compared with the control $\left(25^{\circ} \mathrm{C}\right)$ birds. Feed intake was significantly reduced when exposing the birds to high environmental temperature, because the thermostatic mechanism of feed intake regulation results in an inverse relationship between environmental temperature and the intake of feed and energy (Payne, 1975). During periods of heat stress birds have to make major thermo-regulatoryadaptations in order to prevent death from heat exhaustion. Birds rest more during periods of heat stress and lay sprawled on the litter and spent more time near walls or waterers (May et al., 1997 and Gary and Richard, 1996).

Also, the results indicated that, the light quail line had more heat tolerance than the heavy quail line. Also, the heavy quail line spent significantly more time sitting than the light quail line. A significantly higher walking percentage was observed in the light quail line compared with the heavy quail line. In the preference test, the light quail line spent significantly more time under the high ambient temperatures than the heavy quail line. Also, with regard to latency until panting ( $\mathrm{min}$ ), the heavy quail line started panting significantly earlier than the light quail line. Wilson et al. (1975); Washburn et al, (1980) reported that different quail lines differed in heat tolerance due to differences in body weight and size. The small birds exhibited more heat tolerance. Because small birds have a greater surface area to body mass ratio, they should be able to dissipate heat more efficiently than the heavy quail line.

The results also showed that, the increase in environmental temperature during the rearing phase leads to an increase in the heat tolerance in Japanese quail. The heat tolerance was clearly shown in latency until panting (min) of quail birds (across 15 or $30 \mathrm{~min}$ at $35^{\circ} \mathrm{C}$ heat stress). The increase in respiration rate showed the importance of the role of respiration in losing heat stress. Panting is the most important means of thermoregulation for birds, panting ceased when abdominal temperature was below about $41^{\circ} \mathrm{C}$ (Zhou et al., 1996).

In the present study control birds reared under $25^{\circ} \mathrm{C}$ started panting significantly earlier than the other heated groups. These results indicated that groups heated during the rearing phase had more heat tolerance than the control group. Many workers have demonstrated that the domestic fowl can be protected from the effects of acute heat stress.

Increasing the environmental temperature can lead to increased heat tolerance (such as early age thermal conditioning), lowering the environmental temperature can reduce the bird's ability to tolerance heat stress (Sykes and Fataftah, 1986b; Sykes and Silah, 1986; Arjona et al., 1988; Zhou et al., 1997; Yahav et al., 1997 and Basilio et al., 2001). Chickens could be acclimated to a hot, humid environment by 24 daily $4-h$ exposures to elevated temperatures. The increase in heat tolerance resulting from acclimatization is due to a decrease in body temperature, decreased insensible heat loss, decreased oxygen consumption, and increased panting rates (Sykes and Fataftah, 1986a).

The mechanisms associated with the induction of thermotolerance by early-age 
temperature conditioning involve: 1) modulation of heat production through reducing in plasma triiodothyronine (T3) concentration; 2) hemodynamic changes (decrease in heart weight and hematocrit); 3) increase in sensible heat loss; and 4) pronounced ability to control the body water economy during thermal challenge (Yahav and Plavnik, 1999). Also, from the result of experiment 4 and 5 indicated that, the optimum period of exposure to heat during rearing period to induce heat tolerance in quail lies between 4 to 5 weeks of age.

The temperatures of the leg increased gradually with time to reach a maximum after (5-7 $\mathrm{min}$ ) from the test. After that they remained relatively constant. This result indicate that, increase unfeathered skin temperatures during heat stress, may be increase of skin blood flow in order to increase in heat loss by skin and dissipation the stored heat from unfeathered skin is very important (Zhou et al., 1996).

\section{REFERENCES}

AGEMA, 1992. Thermovision ® 900 Series. User's Manual.

Ali, M.F., S. Khishim, E.A. Kotby and M.E. Mady, 1980. Productive and reproductive performance of Japanese quail under local environmental conditions. 1. Body weight, growth rate, fertility and hatchability. Research Bulletin, No. 1360.

Arjona, A., A. Denbow and JR.W.D Weaver, 1988. Effect of heat stress early life on mortality of broilers exposed to high environmental temperatures just prior to marketing. Poultry Sci. 67:226-231.

Basilio, V., M. Vilarino, S. Ahav and M. Picards, 2001. Early age thermal conditioning and a dual feeding program for male broilers challenged by heat stress. Poultry Sci. 80:29-36.

Bowen, S.J. and K.W. Washburn, 1985. Genetics of heat tolerance in Japanese quail. Poultry Sci. 63 : 430-435.

Deyhim, F. and R.G. Teeter, 1991. Sodium and potassium chloride drinking water supplementation effects on acid-base balance and plasma corticosterone in broilers reared in thermonuteral and heatdistressed environment. Poult. Sci., 70: 2551-2553.

Duncan, D.B., 1955. Multiple range and multiple F-test, Biometrics, 11: 1-42.

Gary, D. B. and D. M. Richard, 1996. Heat stress management in broilers. University of Florida, Co-operative Extension Service (May).

Khalil, H.A., 1998. Seasonal variation in production and fertility of Japanese quail
(Coturinx coturnix japonica). M.Sc. Thesis, Faculty of Agriculture. Suez Canal University, Ismailia, Egypt.

Khalil, H.A., 2004. Productive and reproductive aspects of Japanese quail (Coturnix coturnix japonica) under heat stress conditions. Ph. D. Thesis, Faculty of Agriculture, Suez Canal, University, Ismailia, Egypt.

Khalil, H.A., A.M. Hanafy, Haiam S. Abd Elhalim , Faten A.M. Attia, and M.E. Mady, 2008. Effect of Fasting Periods on Productive Performance and Thyroid Hormones Levels of Japanese Quail Exposed to High Temperature. Agricult. Research J. Suez Canal Uni., Volume 8 (1): 1-8.

Khalil, H.A., Faten A. M. Attia, Haiam S. Abd Elhalim and M.E. Mady, 2007. Efficacy of Dietary Garlic Under Hot Weather in Japanese Quail. Egypt. Poult. Sci., 2007, 27(3): 645-661.

Khalil, H.A., A.M. Hassanein, M.E. Mady, and M. Gerken, 2006. Effect of housing conditions on performance of Japanese quail (Coturnix coturnix japonica) under cold stress in winter. Egypt J. Anim. Prod. 43(1): 71-82.

May, J.D., J. Deaton and A. Branton, 1997. Body temperature of acclimated broilers during exposure to high temperature. Poultry Sci. 66:378-380

Michael, P.L., F.S. Charles and H.B. Fred, 1996. Reducing Poultry losses from heat stress. The University of Georgia College of Agriculture and Environmental Sciences Co-operative Extension Service. Leaflet 333/Revised, 1996.

Payne, C.G., 1975. Day-length during rearing and subsequent egg production of meat strain pullets. British Poultry Sci. 16:559563.

Richard, M., B. Gary and J. Jacquie, 1998. Heat stress in chickens (Physiological adaptation-a matter of survival). Poultry Newsletter, June.

SAS Institute, 1998. SAS statistical guide for personal computer, SAS Institute Inc. Cary, $\mathrm{NC}$.

Siegel, H.S., 1980. Physiological stress in birds. Bio. Sci. 30: 529-534.

Sykes, A.H. and A.R. Fataftah, 1986a. Acclimatization of the fowl to intermittent acute heat stress. British Poultry Sci. 27: 289-300.

Sykes, A.H. and A.R. Fataftah, 1986b. Effect of a change in environmental temperature on heat tolerance in laying fowl. British Poultry Sci. 27: 307-316.

Sykes, A.H. and F.I. Silah, 1986. Effect of changes of dietary energy intake and environmental temperature on heat 
tolerance in the fowl. British Poultry Sci. 27: 687-693.

Washburn, K.W., R. Peavey and G.M. Renwich, 1980. Relationship of strain variation and feed restriction to variation in blood pressure and response to heat stress. Poultry Sci. 59 : 2586-2588.

Wilson, H.R., C.J. Wilcox, R.A. Voitle, C.D. Baird and R.W. Dorminey, 1975. Characteristics of White Leghorn chickens selected for heat tolerance. Poultry Sci. 54: 126-130.

Yahav, S., 2000. Demostic fowl-strategies to confront environmental conditions. Avian. Poultry Biol. Rev. 11:81-95.

Yahav, S. and J.P. McMurtry, 2001. Thermotolerance acquisition in broiler chickens by temperature conditioning earl in life-the effect of timing and ambient temperature. Poultry Sci. 80:1662-1666.

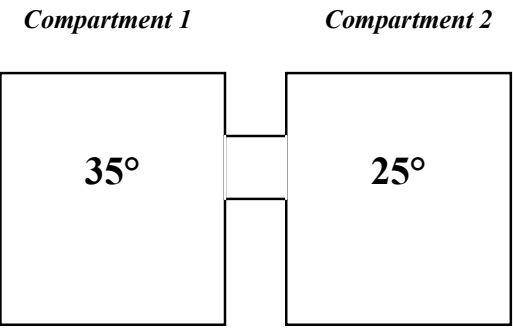

Unit 1 - The first day
Yahav, S. and I. Plavink, 1999. Effect of earlyage thermal conditioning and food restriction of performance and thermotolerance of male broiler chikens. British Poultry Sci. 40:120-126.

Yahav, S., A. Shamai, A. Haberfield, G. Horus, S. Hurwitz, M. Friedman. and I. Plavink, $1997 . \quad$ Induction of thermotolerance in chikens by temperature conditioning: Heat shock protein expression. Update in thermoregulation from cellular function to clinical relevance. Ann. New York Acad. Sci. 813:628-636.

Zhou, W., M. Fujita, T. Ito and S. Yamamoto, 1997. Effects of early heat exposiure on thermoregulatory responses and blood viscosity of broilers prior to marketing. British Poultry Sci. 38: 301-306.

Zhou, W., J. Wang and S. Yamamoto, 1996. Responses of chickens in a warm environment. British Poultry Sci. 827-839.

Compartment 1

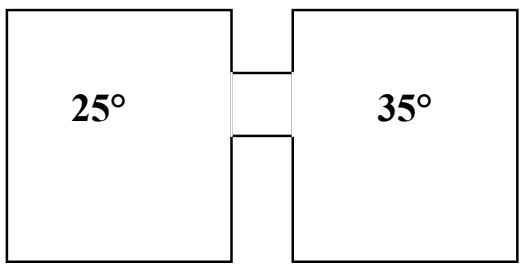

Unit 2- The second day

Figure 1. The two double-caged systems used for the temperature preference test.

Table 1. Basic behavioral activities (\%) in the brooding cage in birds from both quail lines during the rearing phase with respect to rearing temperature (across 5 weeks, means $\pm \mathrm{SE}$ )

\begin{tabular}{cccccc}
\hline Line & Activity & \multicolumn{4}{c}{ Brooding period (weeks) at $35^{\circ} \mathrm{C}$} \\
\cline { 3 - 6 } Light & Standing & $40.6 \pm 1.59^{\mathrm{a}}$ & $40.3 \pm 1.67^{\mathrm{a}}$ & $29.4 \pm 1.43^{\mathrm{b}}$ & $30.4 \pm 1.30^{\mathrm{b}}$ \\
& Sitting & $39.1 \pm 1.97^{\mathrm{c}}$ & $45.5 \pm 1.99^{\mathrm{b}}$ & $54.7 \pm 1.91^{\mathrm{a}}$ & $54.8 \pm 1.48^{\mathrm{a}}$ \\
& Walking & $20.3 \pm 1.36^{\mathrm{a}}$ & $14.2 \pm 1.05^{\mathrm{b}}$ & $15.9 \pm 1.43^{\mathrm{b}}$ & $14.8 \pm 1.13^{\mathrm{b}}$ \\
\hline \multirow{2}{*}{ Heavy } & Standing & $43.6 \pm 2.21^{\mathrm{a}}$ & $36.5 \pm 1.71^{\mathrm{b}}$ & $37.9 \pm 1.54^{\mathrm{b}}$ & $28.9 \pm 1.52^{\mathrm{c}}$ \\
& Sitting & $41.7 \pm 2.34^{\mathrm{c}}$ & $50.5 \pm 2.11^{\mathrm{b}}$ & $51.0 \pm 1.85^{\mathrm{b}}$ & $63.8 \pm 1.34^{\mathrm{a}}$ \\
& Walking & $14.7 \pm 1.26^{\mathrm{a}}$ & $13.0 \pm 1.24^{\mathrm{ab}}$ & $11.1 \pm 0.94^{\mathrm{b}}$ & $7.3 \pm 0.61^{\mathrm{c}}$ \\
\hline a,b,c & & &
\end{tabular}


Table 2. Additional behavioral activities (\%) in the brooding cage in birds from both quail lines during the rearing period at different rearing temperature (across 5 weeks, means $\pm \mathrm{SE}$ )

\begin{tabular}{cccccc}
\hline Line & Activity & \multicolumn{4}{c}{ Brooding period (weeks) at $35^{\circ} \mathrm{C}$} \\
\cline { 2 - 5 } & & $($ Control $) 2$ & 3 & 4 & 5 \\
\hline \multirow{3}{*}{ Light } & Preening & $17.5 \pm 1.12^{\mathrm{a}}$ & $14.5 \pm 1.14^{\mathrm{b}}$ & $10.4 \pm 0.71^{\mathrm{c}}$ & $10.7 \pm 0.61^{\mathrm{c}}$ \\
& Feeding & $10.6 \pm 0.71^{\mathrm{a}}$ & $11.8 \pm 0.86^{\mathrm{a}}$ & $6.7 \pm 0.61^{\mathrm{b}}$ & $6.1 \pm 0.46^{\mathrm{b}}$ \\
& Drinking & $2.2 \pm 0.33^{\mathrm{y}}$ & $2.9 \pm 0.34$ & $2.1 \pm 0.28$ & $2.4 \pm 0.23$ \\
\hline \multirow{3}{*}{ Heavy } & Preening & $11.7 \pm 1.21^{\mathrm{a}}$ & $8.9 \pm 0.84^{\mathrm{b}}$ & $10.7 \pm 0.86^{\mathrm{a}}$ & $8.9 \pm 0.66^{\mathrm{b}}$ \\
& Feeding & $13.5 \pm 1.13^{\mathrm{a}}$ & $10.8 \pm 1.21^{\mathrm{b}}$ & $10.4 \pm 0.73^{\mathrm{b}}$ & $6.2 \pm 0.46^{\mathrm{c}}$ \\
& Drinking & $3.6 \pm 0.46$ & $3.2 \pm 0.47$ & $3.9 \pm 0.42$ & $3.6 \pm 0.42$ \\
\hline
\end{tabular}

a,b,c Means in a row with no common superscript differ significantly $(\mathrm{P} \leq 0.05)$.

Table 3. Preferred ambient temperature (\%) in the two quail lines with respect to rearing temperature at 10 weeks of age (means \pm SE)

\begin{tabular}{cccccc}
\hline \multirow{2}{*}{ Line } & $\begin{array}{c}\text { Preferred } \\
\text { ambient } \\
\text { temp. }\end{array}$ & (Control) 2 & 3 & 4 & 5 \\
\cline { 3 - 6 } Light & $25^{\circ} \mathrm{C}$ & $64.3 \pm 0.04^{\mathrm{b}}$ & $65.7 \pm 0.03^{\mathrm{b}}$ & $62.7 \pm 0.04^{\mathrm{b}}$ & $84.3 \pm 0.05^{\mathrm{a}}$ \\
& $35^{\circ} \mathrm{C}$ & $35.7 \pm 0.04^{\mathrm{a}}$ & $34.4 \pm 0.01^{\mathrm{a}}$ & $37.3 \pm 0.03^{\mathrm{a}}$ & $15.7 \pm 0.03^{\mathrm{b}}$ \\
\cline { 2 - 6 } Heavy & $25^{\circ} \mathrm{C}$ & $78.0 \pm 0.08$ & $82.3 \pm 0.03$ & $89.3 \pm 0.02$ & $89.7 \pm 0.01$ \\
& $35^{\circ} \mathrm{C}$ & $22.0 \pm 0.08$ & $17.7 \pm 0.03$ & $10.7 \pm 0.02$ & $10.3 \pm 0.01$ \\
\hline
\end{tabular}

a,b,c Means in a row with no common superscript differ significantly $(\mathrm{P} \leq 0.05)$.

Table 4. Rectal temperatures $\left({ }^{\circ} \mathrm{C}\right)$ of female quail from the light and heavy lines in relation to short-term heat stress (across 30 minutes) at 18 weeks of age as affected by rearing temperatures (means \pm SE)

\begin{tabular}{|c|c|c|c|c|c|c|}
\hline \multirow[t]{2}{*}{ Traits } & \multirow[t]{2}{*}{ Line } & \multicolumn{4}{|c|}{ Brooding period (weeks) at $35^{\circ} \mathrm{C}$} & \multirow[t]{2}{*}{ Overall } \\
\hline & & (Control) 2 & 3 & 4 & 5 & \\
\hline \multirow{3}{*}{$\mathrm{RTB}^{1}$} & Light & $42.00 \pm 0.06^{\mathrm{ab}}$ & $41.61 \pm 0.05^{\mathrm{bc}}$ & $41.46 \pm 0.03^{c}$ & $42.23 \pm 0.04^{\mathrm{a}}$ & $41.83 \pm 0.05^{\mathrm{B}}$ \\
\hline & Heavy & $42.80 \pm 0.03^{\mathrm{a}}$ & $41.77 \pm 0.03^{b}$ & $42.00 \pm 0.03^{\mathrm{ab}}$ & $42.37 \pm 0.04^{\mathrm{a}}$ & $42.28 \pm 0.03^{\mathrm{A}}$ \\
\hline & Overall & $42.40 \pm 0.06^{\mathrm{a}}$ & $41.69 \pm 0.04^{b}$ & $41.83 \pm 0.04^{b}$ & $42.31 \pm 0.04^{\mathrm{a}}$ & \\
\hline \multirow{3}{*}{ RTA $^{2}$} & Light & $42.70 \pm 0.03^{\mathrm{a}}$ & $42.46 \pm 0.04^{\mathrm{ab}}$ & $42.15 \pm 0.04^{b}$ & $42.62 \pm 0.04^{\mathrm{a}}$ & $42.48 \pm 0.04^{\mathrm{B}}$ \\
\hline & Heavy & $43.60 \pm 0.03^{\mathrm{a}}$ & $42.44 \pm 0.04^{\mathrm{c}}$ & $42.80 \pm 0.03^{b c}$ & $43.00 \pm 0.05^{\mathrm{ab}}$ & $42.96 \pm 0.04^{\mathrm{A}}$ \\
\hline & Overall & $43.15 \pm 0.04^{\mathrm{a}}$ & $42.45 \pm 0.04^{b}$ & $42.47 \pm 0.04^{b}$ & $42.81 \pm 0.03^{\mathrm{ab}}$ & \\
\hline \multirow{3}{*}{$\mathrm{RTD}^{3}$} & Light & $0.70 \pm 0.04^{\mathrm{ab}}$ & $0.85 \pm 0.05^{\mathrm{a}}$ & $0.69 \pm 0.05^{\mathrm{ab}}$ & $0.38 \pm 0.04^{b}$ & $0.66 \pm 0.04$ \\
\hline & Heavy & $0.80 \pm 0.03$ & $0.66 \pm 0.04$ & $0.60 \pm 0.03$ & $0.63 \pm 0.04$ & $0.67 \pm 0.03$ \\
\hline & Overall & $0.75 \pm 0.03$ & $0.76 \pm 0.03$ & $0.65 \pm 0.05$ & $0.51 \pm 0.03$ & \\
\hline
\end{tabular}

Table 5. Leg temperatures $\left({ }^{\circ} \mathrm{C}\right)$ in females from light and heavy quail lines in relation to shortterm heat stress (across 30 minutes) at 18 weeks of age as affected by rearing temperatures (means \pm SE)

\begin{tabular}{|c|c|c|c|c|c|}
\hline \multirow[t]{2}{*}{ Line } & \multicolumn{4}{|c|}{ Brooding period (weeks) at $35^{\circ} \mathrm{C}$} & \multirow[t]{2}{*}{ Overall } \\
\hline & (Control) 2 & 3 & 4 & 5 & \\
\hline Light & $36.89 \pm 0.05^{b}$ & $36.95 \pm 0.04^{b}$ & $37.58 \pm 0.03^{\mathrm{a}}$ & $37.32 \pm 0.03^{\mathrm{ab}}$ & $37.18 \pm 0.04$ \\
\hline Heavy & $37.40 \pm 0.03^{\mathrm{a}}$ & $37.82 \pm 0.03^{\mathrm{a}}$ & $37.82 \pm 0.02^{\mathrm{a}}$ & $36.78 \pm 0.04^{b}$ & $37.43 \pm 0.04$ \\
\hline Overall & $37.14 \pm 0.04^{b}$ & $37.38 \pm 0.05^{\mathrm{ab}}$ & $37.65 \pm 0.02^{\mathrm{a}}$ & $37.05 \pm 0.04^{\mathrm{b}}$ & \\
\hline
\end{tabular}

${ }^{\mathrm{a}, \mathrm{b}}$ Means in a row with no common superscript differ significantly $(\mathrm{P} \leq 0.05)$. 
Table 6. Latency until panting ( $\mathrm{min})$ in females from the light and heavy quail lines with respect to short-term heat stress (across 30 minutes) at 18 weeks of age as affected by rearing temperatures (means $\pm \mathrm{SE}$ )

\begin{tabular}{|c|c|c|c|c|c|}
\hline \multirow[t]{2}{*}{ Line } & \multicolumn{4}{|c|}{ Brooding period (weeks) at $35^{\circ} \mathrm{C}$} & \multirow[t]{2}{*}{ Overall } \\
\hline & (Control) 2 & 3 & 4 & 5 & \\
\hline Light & $6.49 \pm 0.02^{b}$ & $10.25 \pm 0.01^{\mathrm{a}}$ & $8.01 \pm 0.01^{\mathrm{a}}$ & $9.21 \pm 0.01^{\mathrm{a}}$ & $8.39 \pm 0.02^{\mathrm{A}}$ \\
\hline Heavy & $4.08 \pm 0.02^{b}$ & $4.09 \pm 0.01^{b}$ & $5.11 \pm 0.01^{\mathrm{ab}}$ & $8.23 \pm 0.01^{\mathrm{a}}$ & $5.28 \pm 0.01^{\mathrm{B}}$ \\
\hline Overall & $5.48 \pm 0.02^{b}$ & $7.11 \pm 0.02^{\mathrm{ab}}$ & $6.36 \pm 0.01^{b}$ & $8.41 \pm 0.01^{\mathrm{a}}$ & \\
\hline
\end{tabular}

${ }^{\mathrm{a}, \mathrm{b}}$ Means in a row with no common superscript differ significantly $(\mathrm{P} \leq 0.05)$.

${ }^{\mathrm{A}, \mathrm{B}}$ Means in a column with no common superscript differ significantly $(\mathrm{P} \leq 0.05)$.

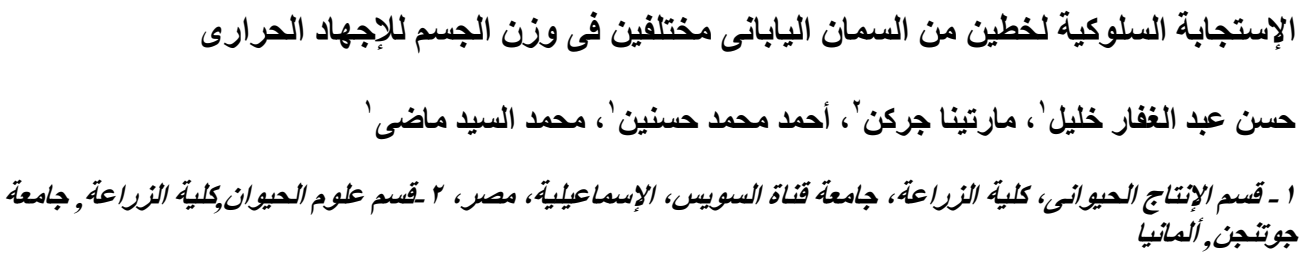

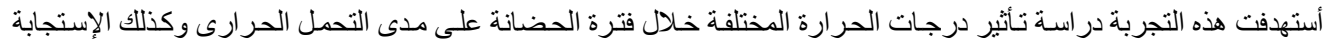

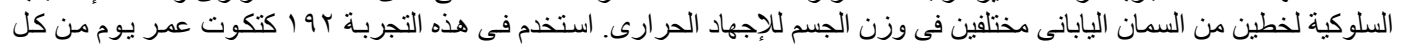

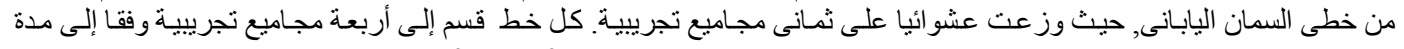

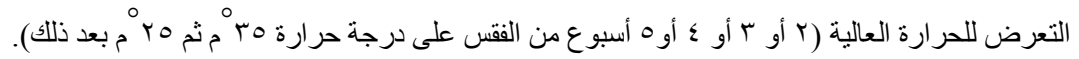

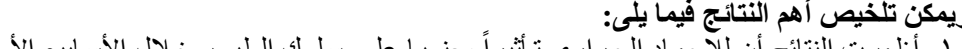

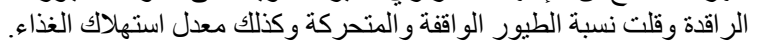

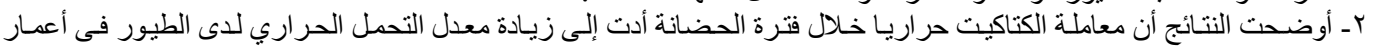
متأخرة. rـ أظهرت النتائج أن السلالة خفيفة الوزن تميزت بنشاطو وبقدرة تحمل حرارى أعلى من السلالة تقبلة الوزن عند التعرض للإجهاد

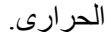

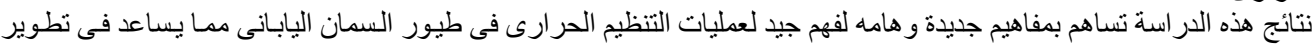

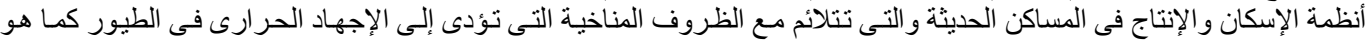

